\title{
PEMANFAATAN AMPAS TAHU SEBAGAI BAHAN BAKU PEMBUATAN BIODIESEL
}

\author{
The Utilization of Tofu Dregs as Raw Material for Biodiesel
}

\author{
*Trisnawati, Daud K. Walanda, dan Irwan Said \\ Pendidikan Kimia/FKIP - Universitas Tadulako, Palu - Indonesia 94118 \\ Received 15 June 2016, Revised 15 July 2016, Accepted 17 August 2016
}

\begin{abstract}
Biodiesel is an alternative raw material for fuel of diesel motor made from vegetable oil. This study attempted to utilize tofu dregs as raw material for biodiesel. This study aimed to determine the yield of biodiesel produced and the content of methyl esters in the biodiesel yield, and to analyze the quality of biodiesel produced based on Indonesian national standard (SNI). This study consisted of four stages: the provision of samples, pre-treatment, esterification and transesterification, and analysis of the quality of biodiesel produced which include the density at $15^{\circ} \mathrm{C}$, the viscosity at $40^{\circ} \mathrm{C}$, and the moisture content. The results showed that the yield of biodiesel was $4.01 \%$, and the content of methyl ester shown by larger $R f(0.87)$ using eluent of hexane:diethylether:formic acid. Results of the analysis of biodiesel quality obtained the density at $15^{\circ} \mathrm{C}$ was $864 \mathrm{~kg} / \mathrm{m} 3$, the viscosity at $40^{\circ} \mathrm{C}$ was $2.57 \mathrm{~mm} 2 / \mathrm{s}$, and the water content was $4 \%$. Based on the parameters of the density at $15^{\circ} \mathrm{C}$ and the viscosity at $40^{\circ} \mathrm{C}$, the product of biodiesel met the requirements of SNI, while in term of the water content the product did not meet the requirements of SNI.
\end{abstract}

Keywords: Tofu dregs; biodiesel; SNI standard; esterification; transesterification

\section{Pendahuluan}

Biodiesel adalah bahan bakar yang terbuat dari bahan yang bersifat dapat diperbarui seperti tumbuh-tumbuhan dan hewanhewanan. Indonesia memiliki keanekaragaman hayati dan hewani yang tinggi, untuk itu terdapat banyak jenis bahan baku biodiesel yang berpotensi untuk dijadikan suplemen bahan bakar motor diesel di Indonesia (Hambali, dkk., 2007). Salah satu bahan alami yang dapat digunakan sebagai material dalam pembuatan biodisel adalah ampas tahu. Ampas tahu merupakan limbah industri pengolahan kedelai menjadi tahu yang kebanyakan hanya digunakan sebagai alternatif bahan pakan ternak (Mahfudz, 2006). Komponen anorganik dalam ampas tahu antara lain adalah kalsium, posforus, dan lain-lain. Sedangkan komponen organik yang dimaksud antara lain lemak dan protein. Protein dalam ampas tahu inilah yang menjadi pertimbangan produksi tempe gembus, sedangkan lemak dalam ampas tahu masih sedikit dikembangkan menjadi sesuatu

\section{*Correspondence:}

Trisnawati

Program Studi Pendidikan Kimia, Fakultas Keguruan dan Ilmu Pendidikan, Universitas Tadulako

email: trissnhakim@gmail.com

Published by Universitas Tadulako 2016 yang bernilai lebih. Lemak dalam ampas tahu tersebut dapat diekstraks untuk mendapatkan minyak yang dapat dimanfaatkan lebih lanjut sebagai bahan baku biodiesel (Buchori, dkk., 2012).

Biodiesel merupakan bahan mentah terbarukan (renewable) yang tersusun dari berbagai macam ester asam lemak yang dapat diproduksi dari minyak-minyak tumbuhan seperti minyak sawit, minyak kelapa, minyak jarak, sampai minyak jelantah. Biodiesel dapat digunakan karena mempunyai sifat fisik mirip dengan solar biasa sehingga dapat diaplikasikan langsung untuk mesin-mesin diesel yang ada, tanpa modifikasi, dan dapat terdegradasi dengan mudah (biodegradable), asap buangan biodiesel tidak hitam, tidak mengandung sulfur sehingga emisi pembakaran yang dihasilkan ramah lingkungan (Prakorso \& Hidayat, 2008)

Asam lemak yang mendominasi ampas tahu adalah asam linoleat yaitu sebesar 51,34$51,69 \%$. Asam linoleat (LA) adalah asam lemak tak jenuh omega-6, secara fisiologis disebut 18:2 (n-6). Secara kimiawi asam linoleat adalah asam yang berantai karbon 18 pada rantai karbon dan 2 cis ikatan rangkap(Damásio, dkk., 2013). Struktur asam linoleat dapat 
dilihat pada Gambar 1 (Scrimgeour, 2005).

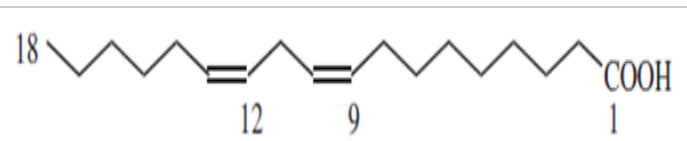

Gambar 1. Struktur Asam Linoleat

Proses umum produksi biodiesel dari bahan baku murah menggunakan asam mineral sebagai katalis, karena jumlah FFA tinggi menyebabkan pembuatan biodiesel dari bahan baku tersebut tidak sesuai dengan katalis basa. Dengan demikian, dua pendekatan alternatif biasanya digunakan, yang pertama adalah proses dua langkah, yang membutuhkan katalis asamawal yang disebut esterifikasi dari FFA, diikuti oleh transesterifikasi triasilgliserol dengan katalis basa. Kedua, proses satu langkah yang hanya menggunakan katalis asam yang secara bersamaan mempromosikan baik esterifikasi dan reaksi transesterifikasi (Cardoso, 2008).

Esterifikasi adalah tahap konversi dari asam lemak bebas menjadi ester. Esterifikasi mereaksikan minyak lemak dengan alkohol dengan katalis yang berkarakter asam kuat(Soerawidjaja, 2006). Transesterifikasi (biasa disebut dengan alkoholisis) adalah tahap konversi dari trigliserida (minyak nabati) menjadi alkil ester, melalui reaksi dengan alkohol dan menghasilkan gliserol(Rutz \& Janse, 2007). Untuk mengetahui kualitas biodiesel yang dihasilkan, maka dilakukan beberapa pengujian parameter dari biodiesel tersebut. Uji parameter dalam penelitian ini dibatasi menjadi tiga parameter yaitu massa jenis, viskositas dan kadar air.

Tujuan dari penelitian ini adalah menentukan rendemen, kandungan metil ester dan menganalisis mutu biodiesel dari ampas tahu yang dihasilkan berdasarkan Standar Nasional Indonesia dilihat dari massa jenis, visositas dan kadar air.

\section{METODE}

\section{Alat dan Bahan}

Alat yang digunakan dalam penelitian ini adalah neraca analitik, termometer, penangas listrik, erlenmeyer, magnetic stirrer, corong pisah, plat TLC, pipa kapiler, stopwatch, piknometer, viskometer Oswald, rotary evaporator, soxhlet ekstraktor, blender, ultra centrifugal mill. Sedangkan bahan yang digunakan dalam oenelitian ini adalah kristal $\mathrm{NaOH}$ (Merck), larutan $\mathrm{NaOH} 0,1 \mathrm{~N}$ (Merck), larutan $\mathrm{H}_{2} \mathrm{O}_{4} 0,05 \mathrm{~N}$ (Merck), asam asetat pekat (Merck), larutan $\mathrm{KOH} \mathrm{0,1} \mathrm{N} \mathrm{(Merck),} \mathrm{asam}$ oksalat (Merck), alkohol 95\%, metanol (Merck), penolphtalein, heksana, eluen heksana:dietil eter:asam formiat (75:25:2), uap iodin.

\section{Cara Kerja}

Sampel yang digunakan adalah ampas tahu yang telah dipisahkan dari limbah cair tahu kemudian dikeringkan kemudian mengekstraknya menggunakan solven heksana dengan metode soxhletasi lalu memisahkan solven dari sampel minyak ampas tahu. Sebelum minyak yang telah diperoleh diolah menjadi biodiesel, terlebih dahulu dilakukan analisis FFA (Free Fatty Acid) atau asam lemak bebas untuk mengetaui proses pembuatan biodiesel. Kadar FFA maksimal pada bahan baku yang akan diproses menjadi biodiesel maksimal adalah 0,5\% (SRS Engineering Corporation, 2008). Kadar FFA yang besar akan mengganggu proses pembentukan biodiesel sehingga perlu dilakukan pretreatment yaitu esterifikasi dengan menggunakan katalis $\mathrm{H}_{2} \mathrm{SO}_{4}$ setelah itu dilakukan tahap transesterifikasi dengan menggunakan katalis $\mathrm{NaOH}$ untuk memisahkan minyak yang mengandung metil ester dengan metil ester (biodiesel) kemudian menentukan rendemen biodiesel yang dihasilkan.

Identifikasi kadar metil ester dalam biodiesel yang dihasilkan menggunakan kromatografi lapis tipis dengan eluen heksan:dietil eter:asam formiat $(75: 25: 2)$. Selanjutnya analisis mutu biodiesel berdasarkan parameter uji massa jenis, viskositas dan kadar air

\section{Hasil dan Pembahasan}

Hasil penelitian pemanfaatan ampas tahu sebagai bahan baku pembuatan biodiesel adalah sebagai berikut:

Tabel 1. Analisis Pendahuluan dan angka asam

\begin{tabular}{cccc}
\hline Analisis & Ulangan I & Ulangan II & Rata-rata \\
\hline FFA (\%) & 0,490 & 0,654 & $\pm 0,572$ \\
Angka Asam I (mgKOH/g) & 0,990 & 1,320 & $\pm 1,155$ \\
Angka Asam II (mgKOH/g) & 0,330 & 0,652 & $\pm 0,491$ \\
\hline
\end{tabular}

Rendemen biodiesel yang diperoleh dari 100 gram minyak ampas tahu pada penelitian ini adalah sebesar $80,13 \%$ berarti $4 \%$ jika diambil dari ampas tahu kering

Adapun ampas tahu yang digunakan dalam penelitian ini adalah ampas tahu kering sebanyak $2 \mathrm{~kg}$ kemudian diekstraksi menghasilkan 114,6 gram minyak hingga menghasilkan biodiesel sebanyak 80,13 gram.

Penelitian yang telah dilakukan diawali dengan penyediaan sampel yaitu ampas tahu dikeringkan kemudian diekstraksi 
Tabel 2. Harga Rf

\begin{tabular}{cc}
\hline Noda & Harga Rf \\
\hline Noda 1 & 0,87 \\
Noda 2 & 0,55 \\
\hline
\end{tabular}

Tabel 3. Analisis Mutu Biodiesel

\begin{tabular}{|ccc}
\hline \multicolumn{3}{c}{ Mutu Biodisel dari Ampas Tahu } \\
\hline Massa jenis pada & Viskositas pada & Penentuan kadar air $(\%)$ \\
temperatur $15{ }^{\circ} \mathrm{C}\left(\mathrm{kg} \mathrm{m}^{3}\right)$ & temperatur $40^{\circ} \mathrm{C}\left(\mathrm{mm}^{2} / \mathrm{s}\right)$ \\
\hline 864 & 2,57 & 4 \\
\hline
\end{tabular}

menggunakan metode soxhletasi dilanjutkan dengan pemisahan minyak ampas tahu dari pelarut heksana sehingga dipeoleh berat minyak sebesar 114,6 gram. Pada penelitian sebelumnya dengan menggunakan pelarut yang sama diperoleh berat minyak sebesar \pm 120 gram (Buchori, dkk., 2012).

Tahap selanjutnya adalah analisis FFA minyak dari ampas tahu, kandungan asam lemak bahan baku (FFA) merupakan salah satu faktor penentu jenis proses pembuatan biodiesel, umumnya minyak bumi memiliki kadar FFA rendah sehingga dapat langsung diproses dengan metode transesterifikasi. Jika kadar FFA minyak tersebut masih tinggi, sebelumnya perlu dilakukan proses praesterifikasi dengan menentukan terlebih dahulu harga FFA minyak (Hambali, dkk., 2007). Analisis kadar FFA ditentukan dengan menggunakan persamaan yang merujuk pada (Santoso, dkk., 2012):

$$
\% \mathrm{FFA}=\frac{\mathrm{N} \mathrm{NaOH} \times \mathrm{mL} \mathrm{NaOH} \times \mathrm{BM} \text { asam lemak }}{\text { berat contoh }(\text { gram }) \times 1000} \times 100 \%
$$

$\% \mathrm{FFA}=$ persentase berat asam lemak tertentu (yang dominan) terhadap minyak/ lemak

Kadar FFA maksimal pada bahan baku yang akan diproses menjadi biodiesel maksimal $0,5 \%$. Hasil analisis FFA yang diperoleh pada penelitian ini adalah $0,572 \%$. Berdasarkan harga FFA yang di peroleh maka proses pembuatan biodiesel dilakukan dua tahap yaitu esterifikasi dan transesterifikasi. Esterifikasi adalah tahap konversi asam lemak bebas menjadi metil ester (Soerawidjaja, 2006). Setelah tahap esterifikasi selanjutnya dilakukan pengujian angka asam yang bertujuan untuk mengetahui jalannya reaksi pengkonversian asam lemak menjadi metil ester dimana angka asam yang disyaratkan dalam pembuatan biodiesel adalah kurang dari $1(0,8 \mathrm{mgOH} / \mathrm{g})$. Angka asam pada tahap esterifikasi dapat ditentukan dengan rumus (Santoso, dkk., 2012):

\section{Angka asam $=\frac{\mathrm{mL} \mathrm{KOH} \times \mathrm{n} \mathrm{KOH} \mathrm{x} \mathrm{56,1}}{\text { berat sampel }(\text { gram })}$}

Jika angka asam yang diperoleh lebih dari 1 berarti tahap pengkonversian tersebut tidak berjalan secara maksimal. Pada penelitian ini diperoleh nilai angka asam sebelum tahap esterifikasi sebesar $1,155 \mathrm{mgOH} / \mathrm{g}$ sedangkan setelah tahap esterifikasi diperoleh angka asam sebesar 0,491 $\mathrm{mgKOH} / \mathrm{g}$, nilai angka asam tersebut telah memenuhi persyaratan yang telah ditetapkan. Tahapan selanjutnya adalah transesterifikasi, transesterifikasi (biasa disebut dengan alkoholisis) adalah tahap konversi dari trigliserida (minyak nabati) menjadi alkil ester, melalui reaksi dengan alkohol dan menghasilkan gliserol (Destiana, dkk., 2007). Mekanisme reaksi transesterifikasi dapat dilihat pada Gambar 2. berikut (Damayanti, 2011):

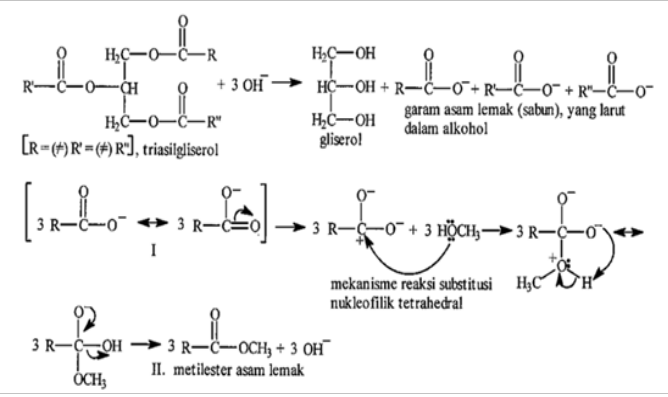

Gambar 2. Mekanisme reaksi transesterifikasi dari asam linoleat

Dari mekanisme reaksi transesterifikasi tersebut terlihat, bahwa $1 \mathrm{~mol}$ triasilgliserol (asam linoleat) akan bereaksi dengan 3 mol basa $(\mathrm{NaOH})$ (proses saponifikasi), menghasilkan $1 \mathrm{~mol}$ gliserol dan $3 \mathrm{~mol}$ garam asam lemak (sabun) yang larut dalam alkohol (metanol). Garam asam lemak yang terbentuk mengalami proses struktur resonansi (I), sehingga hal tersebut menyebabkan reaksi transesterifikasi yang dikatalisis oleh basa bersifat reaksi satu arah dan bukan suatu reaksi kesetimbangan (reversible). Selanjutnya, garam asam lemak akan bereaksi dengan 3 mol metanol, melalui mekanisme reaksi substitusi nukleofilik tetrahedral, membentuk 3 mol metil ester asam lemak dan 3 mol basa. Terlihat bahwa $3 \mathrm{~mol}$ basa pada awal reaksi memang ditambahkan pada reaksi, dan pada akhir reaksi tetap ada (Damayanti, 2011).

Setelah melalui kedua tahapan di atas, dapat diperoleh rendemen biodiesel dari minyak ampas tahu sebesar $80,13 \%$ sedangkan jika dari ampas tahu kering itu sendiri sebesar 4,01\% dengan menggunakan rumus (Khopkar, 2010): 


$$
\mathrm{Rf}=\frac{\text { jarak yang ditempuh oleh komponen }}{\text { jarak yang ditempuh oleh pelarut }}
$$

Harga Rf noda 1 yang diperoleh pada penelitian ini sebesar 0,87 sedangkan harga $\mathrm{Rf}$ metil ester adalah 0,82 sehingga dapat diketahui bahwa komponen yang terbentuk pada noda 1 adalah metil ester. Pada noda yang ke 2 diperoleh harga $\mathrm{Rf}$ sebesar 0,55 sehingga dapat diprediksi komponen yang terbentuk pada noda 2 adalah trigliserida. Hal tersebut didasarkan pada harga $\mathrm{Rf}$ dari trigliserida adalah 0,56, sehingga dapat dikatakan komponen yang terbentuk pada noda 1 adalah metil ester dan noda 2 adalah trigliserida. Berdasarkan dokumentasi penelitian dapat dilihat komponen yang paling atas pada plat TLC lebih besar dari komponen yang berada dibagian bawah sehingga dapat dikatakan kandungan metil ester lebih mendominasi dibandingkan trigliserida dalam rendemen biodiesel.

Berdasarkan hasil penelitian, rendemen biodiesel yang dihasilkan belum memenuhi syarat SNI yaitu sebesar $80,13 \%$ sedangkan dilihat dari syarat SNI rendemen biodiesel minimal $96,5 \%$, hal ini menandakan tahap pengkonversian asam lemak menjadi metil ester belum berjalan maksimal. Oleh karena itu untuk mengetahui apakah rendemen biodiesel (\%) yang dihasilkan dapat digunakan sebagai bahan alternatif pengganti bahan bakar minyak, maka dilakukan analisis lebih lanjut untuk mengetahui mutu biodiesel yang didasarkan pada parameter yang tercantum pada Sandar Nasional Indonesia (SNI). Adapun analisis mutu biodiesel yang dilakukan pada penelitian ini ada tiga yaitu sebagai berikut:

\section{Massa Jenis pada Temperatur $15^{\circ} \mathrm{C}$}

Massa jenis menunjukkan berat per satuan volume. Biodiesel yang memiliki massa jenis melebihi ketentuan akan menghasilkan reaksi pembakaran tidak sempurna. Sehingga akan meningkatkan emisi dan keausan mesin dan meneyebabkan kerusakan pada mesin (Prihandana, 2006). Massa jenis biodiesel pada suhu $15^{\circ} \mathrm{C}$ dapat ditentukan dengan rumus (Dogra \& Dogra, 2009).

$\rho\left(\mathrm{kg} / \mathrm{m}^{3}\right)=\frac{\text { berat biodiesel }(\mathrm{kg})}{\text { volume biodiesel }\left(\mathrm{m}^{3}\right)}$

Penentuan massa jenis pada penelitian ini dilakukan dengan menggunakan piknometer $10 \mathrm{~mL}$, diperoleh massa jenis biodiesel sebesar $864 \mathrm{~kg} / \mathrm{m} 3$ sedangkan bila ditinjau dari massa jenis yang disyaratkan dalam Standar Nasional
Indonesia (SNI), sudah memenuhi standar dimana massa jenis yang disyaratkan dalam SNI adalah (850-890) kg/m3.

Dengan demikian biodiesel yang dihasilkan jika ditinjau dari parameter massa jenis pada temperatur $15^{\circ} \mathrm{C}$ layak digunakan sebagai bahan bakar alternatif pengganti solar karena memenuhi syarat yang ditetapkan dalam SNI

\section{Viskositas pada Temperatur $40^{\circ} \mathrm{C}$}

Viskositas kinematik adalah ukuran mengenai tekanan aliran fluida karena gravitasi, dimana tekanan sebanding dengan kerapatan fluida yang dinyatakan dengan centistoke (cSt). Viskositas yang terlalu tinggi dapat memberatkan beban pompa dan menyebabkan pengkabutan yang kurang baik (Soerawidjaja, 2006).

Viskositas yang terlalu tinggi akan membuat bahan bakar teratomisasi menjadi tetesan yang lebih besar sehingga akan mengakibatkan deposit pada mesin. Tetapi apabila viskositas terlalu rendah akan memproduksi spray yang terlalu halus sehingga terbentuk daerah rich zone yang menyebabkan terjadinya pembentukan jelaga (Prihandana, 2006). Viskositas biodiesel pada temperatur $40^{\circ} \mathrm{C}$ dapat ditentukan dengan (Dogra \& Dogra, 2009).

$$
\eta=\frac{\operatorname{tx} \rho_{0}}{t_{0} \times \rho} \times \eta_{0}
$$

Dimana:

$\eta=$ viskositas biodiesel pada suhu $40^{\circ} \mathrm{C}\left(\mathrm{mm}^{2} / \mathrm{s}\right) ; \eta_{0}=$ viskositas aquades pada suhu $40^{\circ} \mathrm{C}\left(\mathrm{mm}^{2} / \mathrm{s}\right) ; \mathrm{t}=$ waktu alir biodiesel $(\mathrm{s}) ; \mathrm{t}_{0}=$ waktu alir aquades $(\mathrm{s}) ; \rho=$ massa jenis biodiesel pada suhu $40^{\circ} \mathrm{C}\left(\mathrm{kg} \mathrm{m} \mathrm{m}^{3}\right)=$ massa jenis biodiesel pada suhu $15^{\circ} \mathrm{C} ; \rho_{0}=$ massa jenis aquades pada suhu $40^{\circ} \mathrm{C}\left(\mathrm{kg} \mathrm{m}^{3}\right)$

Hasil pengukuran viskositas pada temperatur $40^{\circ} \mathrm{C}$ diperoleh pada penelitian ini sebesar 2,57 $\mathrm{mm} 2 / \mathrm{s}$. Viskositas yang ditetapkan SNI adalah 2,3-6,0 $\mathrm{mm}^{2} / \mathrm{s}$. Berdasarkan persyaratan SNI dan hasil pengukuran dapat dikatakan biodiesel yang dihasilkan pada penelitian ini telah memenuhi syarat dan dapat digunakan sebagai bahan bakar alternatif pengganti solar ditinjau dari parameter viskositas pada temperatur 40 ${ }^{\circ} \mathrm{C}$.

Penentuan Kadar Air

Kualitas biodiesel ditentukan oleh kemurnian senyawa metil ester di dalam biodiesel. Senyawa kontaminan yang terdapat di dalam biodiesel dapat menyebabkan permasalahan ketika penggunaan biodiesel pada mesin. Kontaminan dapat menyebabkan timbulnya kerak pada mesin dan penyumbatan pada saluran injeksi. Kontaminan yang terdapat 
pada biodiesel dapat berupa asam lemak bebas, gliserol, air dan mono-, di- dan trigliserida yang masih terdapat pada biodiesel(Knothe, 2006).

Pemurnian biodiesel juga dapat dilakukan dengan metode dry washing, pada metode dry washing, magnesium silikat menggantikan peran air dalam menyerap kontaminan dalam biodiesel. Magnesium silikat dapat menurunkan kadar gliserol dan sangat efektif untuk menghilangkan sabun. Magnesium silikat $\left(\mathrm{Mg}_{3} \mathrm{Si}_{4} \mathrm{O}_{10}(\mathrm{OH})_{2}\right)$ mampu menyerap sisa methanol, sisa katalis, sabun dan gliserol dalam biodiesel(Ayu \& Zibbeni, 2012).

Penentuan kadar air dilakukan dengan cara memanaskan gelas kimia dalam oven kemudian dikeringkan dalam desikator. Gelas kimia yang didinginkan kemudian ditimbang untuk mengetahui berat gelas kimia kosong tersebut kemudian ditambahkan minyak sebanyak 5 gram dan diuapkan dalam oven pada temperatur $105 \mathrm{oC}$. Air dapat menguap pada $100 \mathrm{oC}$ sehingga digunakan temperatur tersebut agar kadar air yang ada dalam biodiesel yang dihasilkan dapat berkurang. Kadar air ditentukan dengan rumus (Khopkar, 2010).

$$
\text { kadar air }=\frac{A-B}{A} \times 100 \%
$$

Dimana: $\mathrm{A}=$ berat sampel sebelum dipanaskan (gram) dan B = berat sampel setelah dipanaskan (gram)

Berdasarkan syarat biodiesel dalam SNI kandungan air dalam biodiesel maksimal 0,05\%. Kadar air yang dihasilkan dari penelitian ini sangat besar yaitu $4 \%$, salah satu penyebab tingginya kadar air yaitu pada proses pemurniannya yang menggunakan asam asetat dan aquades, biodiesel yang dihasilkan terkontaminasi airdan pada pemisahannya belum maksimal sehingga masih ada kandungan air yang tertinggal di dalam biodiesel tersebut.

Pemurnian biodiesel juga dapat dilakukan dengan metode dry washing, pada metode dry washing, magnesium silikat menggantikan peran air dalam menyerap kontaminan dalam biodiesel. Magnesium silikat dapat menurunkan kadar gliserol dan sangat efektif untuk menghilangkan sabun. Magnesium silikat $\left(\mathrm{Mg}_{3} \mathrm{Si}_{4} \mathrm{O}_{10}(\mathrm{OH})_{2}\right)$ mampu menyerap sisa methanol, sisa katalis, sabun dan gliserol dalam biodiesel.

Berdasarkan ketiga parameter uji yang dilakukan dalam penelitian ini dapat diketuhi bahwa biodiesel yang dihasilkan memenuhi SNI ditinjau dari parameter massa jenis pada temperatur $15^{\circ} \mathrm{C}$ dan viskositas pada temperatur $40^{\circ} \mathrm{C}$. Sedangkan jika ditinjau dari parameter kadar air rendemen biodiesel yang dihasilkan belum memenuhi SNI.

\section{Kesimpulan}

Rendemen biodiesel yang dihasilkan dari ampas tahu adalah sebesar $4,01 \%$ sedangkan dilihat dari mutu biodiesel yang dihasilkan memenuhi Standar Nasional Indonesia jika ditinjau dari parameter massa jenis pada temperatur $15^{\circ} \mathrm{C}$ sebesar $864 \mathrm{~kg} / \mathrm{m} 3$ dan viskositas pada temperatur $40^{\circ} \mathrm{C}$ sebesar 2,57 $\mathrm{mm}^{2} / \mathrm{s}$, kemudian ditinjau dari parameter analisis kadar air yang dihasilkan sebesar $4 \%$ belum memenuhi Standar Nasional Indonesia untuk biodiesel sehingga kemungkinan masih ada kontaminan air yang terdapat dalam biodiesel.

\section{Ucapan Terima Kasih}

Penulis mengucapkan terima kasih kepada kepala laboran laboratorium Kimia FKIP dan semua pihak yang telah membantu dalam pelaksanaan penelitian ini.

\section{Referensi}

Ayu, D., \& Zibbeni, A. (2012). Pengaruh stir washing, bubble washing, dan dry washing terhadap kadar metil ester dalam biodiesel dari biji nyamplung (calophyllum inophyllum). from http://digilib.its.ac.id/ public/ITS-Undergraduate-10543-Paper. pdf

Buchori, L., Sasongko, S. B., Anggoro, D. D., \& Aryanti, N. (2012). Pengambilan minyak kedelai dari ampas tahu sebagai bahan baku pembuatan biodiesel. Jurnal Ilmu Lingkungan, 10(2), 49-53.

Cardoso, A. L., Neves, S. C. G and Silva, M. J. (2008). Esterification of oleic acid for biodiesel production catalyzed by $\mathrm{SnCl} 2$ : a kinetic investigation. Article. 10.3390/ en1020079.

Damásio, J. M. A., Requião, L. A., Santana, D. A., Silva, M. V., de Souza, N. E., Coró, F. A. G., \& Simionato, J. I. (2013). Lipid stability of soybeans in grains and soybeans srocessed as tofu. Journal of Agricultural Science, 5(11), 67-74.

Damayanti, A. (2011). Pembuatan metil ester (biodiesel) dari biji ketapang. Jurnal Kompetensi Teknik, 3(1), 41-46.

Destiana, M., Zandy, A., Nazef, \& Puspasari, S. 
(2007). Intensifikasi proses produksi biodiesel. Bandung: Institut Teknologi Bandung

Dogra, S. K., \& Dogra, S. (2009). Kimia fisik dan soal-soal. Jakarta: UI-Press.

Hambali, E., Mujdalifah, S., Halomoan, A., Tambunan, Pattiwiri, A. W., \& Hendroko, R. (2007). Teknologi bioenergi. Jakarta: PT. Agro Media Pustaka.

Khopkar, S. M. (2010). Konsep dasar kimia analitik. . Jakarta: UI-Press.

Knothe, G. (2006). Analyzing biodiesel: standards and other methods. Journal of American Oil Chemists' Society, 8(3), 823833.

Mahfudz, L. D. (2006). Efektifitas oncom ampas tahu sebagai bahan pakan ayam pedaging. Animal Production, 2(8), 108114.

Prakorso, T., \& Hidayat, N. A. (2008). Potensi biodiesel indonesia. from http://www. migas-Indonesia.com/files/article/Potensi_
Bodiesel.doc

Prihandana, R. H. (2006). Menghasilkan biodiesel murah. Jakarta: PT. Agro Media Pustaka.

Rutz, D., \& Janse, R. (2007). Biofuel technology handbook. Germany: WIP Renewable Energies.

Santoso, U., Sudarmanto., Naruki, S., \& Fibri, D. L. N. (2012). Analisis pangan dan hasil pertanian I. Yogyakarta: Universitas Gajah Mada.

Scrimgeour, C. (2005). Chemistry of fatty acid. Scotland: Scottish Crop Research Institute Dundee.

Soerawidjaja, T. H. (2006). Fondasi-fondasi ilmiah dan keteknikan dari teknologi pembuatan biodiesel. Yogyakarta: Universitas Gajah Mada.

SRS Engineering Corporation. (2008). . USA: Patent Pending Technology. 